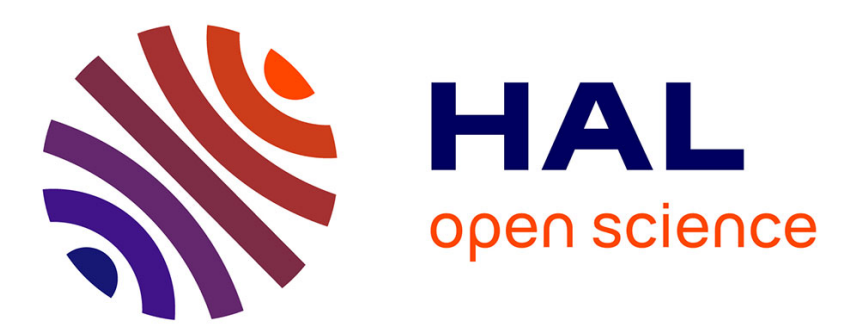

\title{
Uncommonly thorough hydrolysis of peptides during ripening of Ragusano cheese revealed by tandem mass spectrometry
}

Valérie Gagnaire, Stéfania Carpino, Concetta Pediliggieri, Julien Jardin, Sylvie Lortal, Giuseppe Licitra

\section{To cite this version:}

Valérie Gagnaire, Stéfania Carpino, Concetta Pediliggieri, Julien Jardin, Sylvie Lortal, et al.. Uncommonly thorough hydrolysis of peptides during ripening of Ragusano cheese revealed by tandem mass spectrometry. Journal of Agricultural and Food Chemistry, 2011, 59 (23), pp.12443-12452. 10.1021/jf2027268 . hal-01454142

\author{
HAL Id: hal-01454142 \\ https://hal.science/hal-01454142
}

Submitted on 29 May 2020

HAL is a multi-disciplinary open access archive for the deposit and dissemination of scientific research documents, whether they are published or not. The documents may come from teaching and research institutions in France or abroad, or from public or private research centers.
L'archive ouverte pluridisciplinaire HAL, est destinée au dépôt et à la diffusion de documents scientifiques de niveau recherche, publiés ou non, émanant des établissements d'enseignement et de recherche français ou étrangers, des laboratoires publics ou privés. 


\title{
Uncommonly Thorough Hydrolysis of Peptides during Ripening of Ragusano Cheese Revealed by Tandem Mass Spectrometry
}

\author{
Valérie Gagnaire, ${ }^{,+,+\neq}$Stefania Carpino, ${ }^{\S}$ Concetta Pediliggieri, ${ }^{\S}$ Julien Jardin, ${ }^{+, \ddagger}$ Sylvie Lortal, ${ }^{+, \neq}$and \\ Giuseppe Licitra $\$, \nabla$ \\ ${ }^{\dagger}$ UMR 1253, INRA, Science et Technologie du Lait et de l'cEuf, 65 rue de Saint Brieuc, F-35042 Rennes, France \\ ${ }^{\ddagger}$ UMR 1253, Agrocampus Ouest, Science et Technologie du Lait et de l'Euf, 65 rue de Saint Brieuc, F-35042 Rennes, France \\ ${ }^{\S}$ CoRFiLaC, $25 \mathrm{Km}$ 5, Ragusa Mare, 97100 Ragusa, Italy \\ ${ }^{\nabla}$ Department of Agriculture and Food Production Science, Catania University, via Valdisavoia 5, 95100 Catania, Sicily, Italy
}

ABSTRACT: Ragusano is a pasta filata cheese produced from raw milk in Sicily. The proteolysis was extensively analyzed after stretching (day 0 ), at 4 and 7 months of ripening through soluble nitrogen, urea-PAGE, and peptide identification by tandem mass

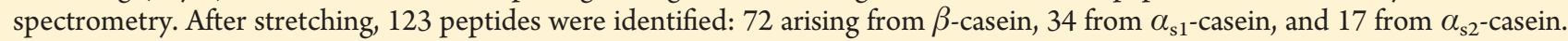
The main protein splitting corresponded to the action of plasmin, chymosin, cathepsin $\mathrm{D}$, cell envelope proteinase, and peptidase activities of lactic acid bacteria. Unlike other types of cheeses, $<10 \%$ residual $\beta$ - and $\alpha_{\mathrm{s}}$-caseins remained intact at 7 months, indicating original network organization based on large casein fragments. The number of identified soluble peptides also dramatically decreased after 4 and 7 months of ripening, to 47 and 25, respectively. Among them, bioactive peptides were found, that is, mineral carrier, antihypertensive, and immunomodulating peptides and phosphopeptides.

KEYWORDS: Ragusano cheese, tandem mass spectrometry, peptide, proteolysis, ripening

\section{INTRODUCTION}

Proteolysis is regarded as a complex and essential biochemical process contributing to the texture and flavor development occurring during the ripening of most cheese varieties. Proteolytic agents originate from three sources: milk, coagulant, and microflora including starter, nonstarter lactic acid bacteria, and secondary microflora. ${ }^{1,2}$ The breakdown of caseins into largeand medium-sized peptides due to the concerted action of proteinases from residual coagulant, milk, and microflora causes the major modifications occurring in cheese texture during the primary phase of ripening. The preliminary splitting of $\alpha_{\mathrm{s} 1}$-casein into $\alpha_{\mathrm{s} 1}-\mathrm{CN}(1-23)$ and $\alpha_{\mathrm{s} 1}-\mathrm{CN}(24-199)$ by the chymosin has been particularly associated with the initial softening of the cheese structure. ${ }^{3}$ Primary peptides released from the activities of chymosin and plasmin depending on the technology can also contribute directly to off-flavor formation in cheese; indeed, some peptides derived from the highly hydrophobic regions of caseins may cause bitterness if they accumulate in cheese, as well as some small peptides interfering with calcium and magnesium ions and producing a broth-like aroma. ${ }^{2}$ Nevertheless, large peptides and oligopeptides are mostly involved in positive flavor formation in cheese by serving as substrates for the enzymatic activities of microflora. Cell-envelope proteinases (CEP) of lactic acid bacteria release high numbers of peptides from caseins, which are further degraded into smaller peptides and free amino acids (FAA) by intracellular peptidases. Sapid compounds (amines, acids, $\mathrm{NH}_{3}$, and thiols) derived from these substrates as well as flavor compounds from amino acid catabolism (esters, aldehydes, ketones, alcohols. etc.) are then produced, leading to the characteristic cheese flavor. $^{4-6}$

Ragusano is a pasta filata cheese produced in the Hyblean region of Sicily (Italy) according to a traditional technology. ${ }^{7}$
It is exclusively produced from bovine raw milk and coagulated with lamb rennet paste. Ragusano cheese is salted by brine immersion and aged for up to 12 months. Traditional manufacture and product characteristics allowed Ragusano to gain the status of Protected Denomination of Origin cheese. ${ }^{8-10}$ Proteolysis occurring in Ragusano cheese during aging has been described by using a combination of electrophoretic, chromatographic, and chemometric approaches. Patterns of primary proteolysis by urea-polyacrylamide gel electrophoresis (ureaPAGE) have shown the major role played by chymosin and plasmin in the hydrolysis of caseins into large- and medium-sized peptides. $^{11,12}$

A recent breakthrough in the methods of peptide identification throughout cheese ripening has provided the opportunity to better understand the overall proteolytic process acting in cheese. The general strategy, that is, extraction of peptide fractions from cheese, use of chromatographic techniques, and their subsequent identification by mass spectrometry, allowed extensive investigation of the mechanisms of proteolysis involved in the maturation of different varieties of cheese such as Cheddar, ${ }^{13,14}$ Emmental, ${ }^{15}$ Grana Padano, ${ }^{16,17}$ Manchego, ${ }^{18,19}$ and Parmigiano Reggiano. $^{20,21}$

The technology of pasta filata cheeses differs drastically from other cheese varieties in using hot water (around $85{ }^{\circ} \mathrm{C}$ ) to stretch the curd, the temperature of which reaches about $50^{\circ} \mathrm{C}$. This can lead to original features in casein network organization and thus in its subsequent proteolysis during ripening. However,

Received: July 8, 2011

Revised: October 19, 2011

Accepted: October 22, 2011

Published: October 22, 2011 
Table 1. Physicochemical Characteristics of Ragusano Cheeses during Aging

\begin{tabular}{|c|c|c|c|c|c|c|}
\hline & \multicolumn{3}{|c|}{ mountain } & \multicolumn{3}{|c|}{ sea } \\
\hline & 0 months & 4 months & 7 months & 0 months & 4 months & 7 months \\
\hline $\mathrm{pH}$ & $5.06 \pm 0.03$ & $5.61 \pm 0.13$ & $5.70 \pm 0.21$ & $5.07 \pm 0.14$ & $5.45 \pm 0.06$ & $5.48 \pm 0.00$ \\
\hline $\mathrm{TS}^{a}$ & $54.33 \pm 0.31$ & $66.04 \pm 1.48$ & $67.59 \pm 1.42$ & $55.67 \pm 0.83$ & $63.75 \pm 0.90$ & $65.24 \pm 0.85$ \\
\hline protein, ${ }^{b} \%$ & $24.27 \pm 0.47$ & $27.69 \pm 0.25$ & $28.07 \pm 0.37$ & $26.95 \pm 0.95$ & $29.67 \pm 1.49$ & $30.25 \pm 0.86$ \\
\hline fat in dry matter, \% & $51.09 \pm 4.76$ & $48.19 \pm 0.98$ & $47.72 \pm 1.65$ & $46.49 \pm 1.82$ & $46.28 \pm 1.42$ & $44.25 \pm 3.08$ \\
\hline $\mathrm{pH} 4.6 \mathrm{SN} /$ total N, ${ }^{c} \%$ & $4.45 \pm 0.90$ & $17.60 \pm 2.74$ & $20.57 \pm 2.25$ & $2.62 \pm 0.75$ & $21.77 \pm 0.56$ & $25.74 \pm 2.21$ \\
\hline TCA SN/total N, ${ }^{d} \%$ & $1.95 \pm 0.63$ & $14.88 \pm 2.57$ & $17.52 \pm 2.97$ & $1.14 \pm 0.43$ & $17.27 \pm 0.63$ & $21.37 \pm 2.77$ \\
\hline TCA SN/pH 4.6 SN, ${ }^{e} \%$ & $42.99 \pm 5.52$ & $84.44 \pm 4.46$ & $84.92 \pm 7.44$ & $42.99 \pm 6.76$ & $79.33 \pm 2.54$ & $83.00 \pm 8.49$ \\
\hline
\end{tabular}

${ }^{a}$ TS, total solid. ${ }^{b}$ Protein $\%=$ total $\mathrm{N} \times 6.38 .{ }^{c} \mathrm{pH} 4.6 \mathrm{SN} /$ total N, $\mathrm{pH} 4.6$ acetate buffer-soluble $\mathrm{N}$ as a percentage of total N. ${ }^{d} \mathrm{TCA}$ SN/total N, $12 \%$ TCA-soluble $\mathrm{N}$ as a percentage of total $\mathrm{N} .{ }^{e}$ TCA SN/pH $4.6 \mathrm{SN}=12 \%$ TCA-soluble $\mathrm{N}$ as a percentage of $\mathrm{pH} 4.6$ acetate buffer-soluble N.

to the best of our knowledge, only partial characterization of peptides released during proteolysis has been performed in this family of cheesemaking technology. ${ }^{22}$ As Ragusano cheese is a rare pasta filata cheese with long-term ripening, it represents an excellent model to characterize proteolytic events in these cheeses. Thus, the objective of this study was to identify the extent of casein hydrolysis and the peptides released in the watersoluble fraction of Ragusano cheese. The potential presence of bioactive peptides was also investigated.

\section{MATERIALS AND METHODS}

Cheese Sampling. The experiment was carried out by collecting milk from two different farms, located at seaside and mountain levels to increase the variability of milk composition, before cheeses were manufactured in the same pilot plant and under the same cheesemaking conditions. Four cheeses were manufactured per type of milk in the experimental dairy plant at $\mathrm{CoRFiLaC}$, a dairy research center located in Ragusa province in Italy, according to the traditional technology. ${ }^{7}$ Cheeses were sampled at different ripening times ( 0 , just after stretching, and 4 and 7 months) and stored at $-20^{\circ} \mathrm{C}$ for further analyses.

Compositional Analysis. Twenty-four samples of grated cheese were analyzed in duplicate. Cheese analyses were as follows: moisture, total nitrogen (TN) by the Kjeldahl method, ${ }^{23}$ fat in dry matter (FDM) by the Gerber method, ${ }^{24}$ and $\mathrm{NaCl}$ by the Volhard method. ${ }^{25}$ Total solids were determined using a forced-air oven-drying method at $100{ }^{\circ} \mathrm{C}$ for $24 \mathrm{~h}$ (AOAC, 2000), whereas $\mathrm{N}$ soluble in $\mathrm{pH} 4.6$ acetate buffer $(\mathrm{pH}$ 4.6 SN) and 12\% TCA-soluble N (TCA SN) were determined and expressed as a percentage of the total content. ${ }^{26}$

Assessment of Proteolysis. The $\mathrm{pH}$ 4.6-insoluble $\mathrm{N}$ of the cheeses was prepared as described by Fallico et al. ${ }^{11}$ These fractions were analyzed by urea-PAGE using a Protean IIxi vertical slab gel unit (Bio-Rad Laboratories Ltd., Watford, Herts. U.K.) according to the method of Andrews. ${ }^{27}$ The gels were stained using a modification of the method of Blakesley and Boezy ${ }^{28}$ with Coomassie Brillant Blue (G250). The urea-PAGE gels were scanned using a GS-710 calibrated imaging densitometer (Bio-Rad Laboratories Ltd., Hercules, CA).

Peptide Identification by Reversed Phase (RP) HPLC Coupled to Tandem Mass Spectrometry (MS/MS). The water-soluble nitrogen (WSN) fraction was extracted from cheese samples as described by Kuchroo and Fox. ${ }^{29}$ A mixture of grated cheese and water $(1: 2, \mathrm{w} / \mathrm{w})$ was homogenized by using a stomacher at $20{ }^{\circ} \mathrm{C}$ for $10 \mathrm{~min}$. After heating at $40{ }^{\circ} \mathrm{C}$ for $1 \mathrm{~h}$, the homogenate was centrifuged at $4290 \mathrm{rpm}$ for $30 \mathrm{~min}$ at $4{ }^{\circ} \mathrm{C}$, and the supernatant was filtered through Whatman no. 113. Aliquots of the filtrate (WSN) were freeze-dried and stored at $-20{ }^{\circ} \mathrm{C}$ until analysis by RP-HPLC. The identification of peptides in the WSN of Ragusano cheese was carried out by preparing samples as follows. The WSN extracts were dialyzed against water using a dialysis membrane with a cutoff of $500 \mathrm{Da}$ (Spectra por Biotech cellulose ester dialysis membrane, Medicell International Ltd., London, U.K.) and then adjusted to $\mathrm{pH} 7.0$ by means of a $25 \% \mathrm{NH}_{4}$ solution before freeze-drying. The freeze-dried samples $(10 \mathrm{mg})$ were dissolved into $0.2 \%$ TFA $(1 \mathrm{~mL})$ and then centrifuged for $1 \mathrm{~min}$ at room temperature. The supernatant $(1 \mathrm{~mL})$ was recovered, filtered through a $0.45 \mu \mathrm{m}$ filter, and diluted in the ratio 1:10 using TFA $0.1 \%$; then $10 \mu \mathrm{L}$ was injected onto a $\mathrm{C}_{18}$ capillary Nanocolumn (PepMap $\mathrm{C}_{18}, 3 \mu \mathrm{m}$, $100 \AA, 75 \mu \mathrm{m}$ i.d. $\times 15 \mathrm{~cm}$, LC Packings), with the same gradient as used by Gagnaire et al. ${ }^{15}$ at a flow rate of $200 \mathrm{~nL} / \mathrm{min}$. The chromatographic nano LC Ultimate system (LC-Packings, Dionex, Voisins Le Bretonneux, France) was coupled online with a hybrid quadrupole time-of-flight (Q/TOF) mass spectrometer QStar XL (MDS Sciex, Toronto, Canada) equipped with an atmospheric pressure electrospray ionization source (ESI). The instrument was calibrated with a multipoint calibration using fragment ions that resulted from the collision-induced decomposition (CID) of peptide from $\beta$-casein, $\beta$ - $\mathrm{CN}(193-209)$.

The mass spectrometer was operating in positive ion mode. A voltage of around $2 \mathrm{kV}$ was applied to the nanoflow probe tip. MS and MS/MS data were acquired in continuum mode. Data-direct analysis was employed to perform MS/MS analysis on doubly and triply charged precursor ions. Precursor selection was based upon ion intensity and charge state, and, if precursor had been previously selected for interrogation, they were excluded. Spectra were collected in the selected mass range $m / z 350-2000$ for MS, and MS/MS spectra were collected from $m / z 50$ to 2000 . The mass spectrometer was operated in data-dependent mode automatically switching between MS and MS/MS acquisition using Analyst QS 1.1 software. To identify peptides, all data (MS and MS/MS) were then submitted to MASCOT (v.2.1). The search was performed against a homemade database dealing with major milk proteins, which represents a portion of the Swissprot database (http:// www.expasy.org). No specific enzyme cleavage was used, and the peptide mass tolerance was set to $0.3 \mathrm{Da}$ for MS and 0.2 Da for MS/MS. Three variable modifications (phosphorylation on serine and threonine, oxidation of methionine, and deamidation of asparagine and glutamine residues) were selected.

\section{RESULTS AND DISCUSSION}

Chemical Composition of Cheese and Extent of Proteolysis. The average values for protein content, as reported in Table 1, increased from 24.3 to $28.1 \%$ ( $\mathrm{g} \mathrm{N}$ equiv protein $/ 100 \mathrm{~g}$ of cheese) in cheeses manufactured with mountain milk and from 26.9 to $30.2 \%$ by using sea milk from 0 to 7 months of ripening, and those for fat content decreased from 51.5 to $47.7 \%$ fat in dry matter and from 46.5 to $44.2 \%$, respectively. These values are in 


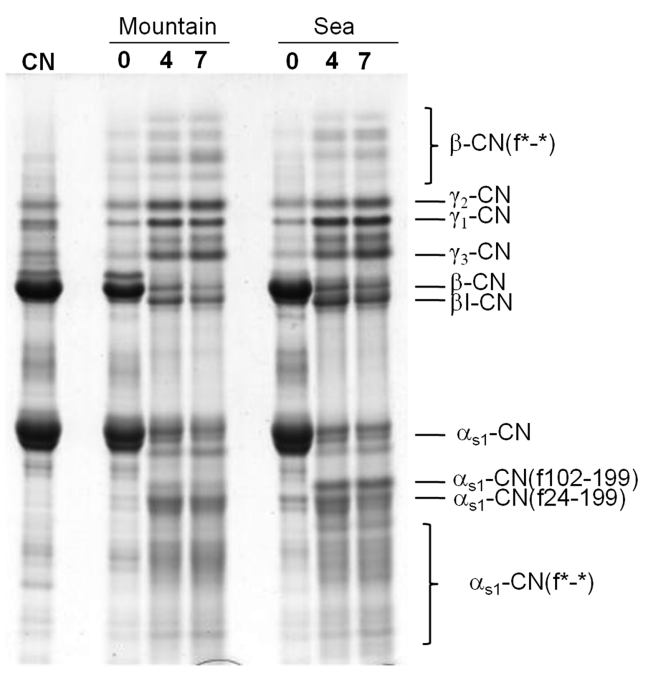

Figure 1. Urea-polyacrylamide gel electrophoretograms ( $\mathrm{pH} 8.6$ ) of the water-insoluble $\mathrm{N}$ fractions from cheese after stretching (0) and after 4 months (4) and 7 months (7) of aging. CN corresponds to whole caseins used as a standard. Cheeses were manufactured from milk collecting in two different farms, located at different altitudes.

agreement with previous compositional studies on this pasta filata cheese. ${ }^{11,12,30,31}$ As Ragusano cheese is a brine-salted cheese and ripened without packaging, an increase in salt moisture ratio, and consequently in protein content, throughout ripening time is generally observed. The slight decrease in fat could be attributed to a loss of fat at the surface of the cheese blocks, when they shrink during aging. ${ }^{31}$

With regard to proteolysis indices, the content of $\mathrm{pH} 4.6$ soluble nitrogen $(\mathrm{SN})$, expressed as percentage of the total nitrogen, increased from 4.5 to $20.6 \%$ from 0 to 7 months of ripening. Such an increase was observed also in Caciocavallo Pugliese cheeses. ${ }^{32}$ In parallel, the content in small peptides present in $12 \%$ TCA precipitate soluble nitrogen expressed as percentage of the total nitrogen also greatly increased from 1.9 ( 0 months) to $17.5 \%$ ( 7 months). For the cheeses made from the milk at seaside, the amount in small peptide was slightly higher, in agreement with the initial higher protein content. The proportion of the ratio TCA SN/pH 4.6 SN gave information on the types of peptides produced throughout aging. This ratio was the same for both series of cheeses, indicating a same general pathway for casein degradation. Thus, in the 0 month cheese almost a half $(43 \%)$ of the peptides produced is composed of small peptides and free amino acids. This content in small peptides and free amino acids reached $>80 \%$ at the end of the ripening period. This ratio is higher than in other pasta filata cheeses such as mozzarella cheese, in which the ratio TCA SN/ $\mathrm{pH} 4.6 \mathrm{SN}$ did not exceed $15 \%$ after 70 days of ripening. ${ }^{33}$ This ratio is also higher than in other hard cheeses such as Comté, ${ }^{34}$ with a maximum of $50 \%$ of the ratio TCA SN/pH $4.6 \mathrm{SN}$, but similar to that observed in Parmigiano Reggiano, that is, $88 \%$ between 6 and 10 months of ripening. ${ }^{35}$ This high proportion of small peptides and free amino acids is also indicative of the major role played by microflora proteolytic enzymes.

Casein Hydrolysis. Primary proteolysis in Ragusano cheeses after 0, 4, and 7 months of aging is shown in Figure 1 as ureaPAGE profiles of the water-insoluble nitrogen fractions. The extent of casein degradation was largely affected by aging as previously demonstrated. ${ }^{11}$ The urea-PAGE profiles of experimental cheeses made from raw milk from the farms at the different altitude levels were very similar, and hydrolysis of $\beta$ - and $\alpha_{\mathrm{s} 1^{-}}$ caseins was almost completed at 4 months, because no obvious modification was seen between 4 and 7 months of aging in both cheeses, regardless of the location of the farms. Moreover, a gradual decrease between 0 and 4 months was also observed (data not shown). The main proteolytic enzymes are (i) plasmin through the presence of the peptides $\beta-\mathrm{CN}(29-209)\left(\gamma_{1}-\mathrm{CN}\right)$, $\beta$-CN $(106-209)\left(\gamma_{2}-\mathrm{CN}\right)$, and $\beta-\mathrm{CN}(108-209)\left(\gamma_{3}-\mathrm{CN}\right)$ and (ii) chymosin (and/or cathepsin D) through the presence of peptides $\beta$-CN $(1-192)(\beta \mathrm{I}-\mathrm{CN})$ and $\alpha_{\mathrm{s} 1}-\mathrm{CN}(24-199)\left(\alpha_{\mathrm{s} 1}-\mathrm{I}\right)$ and to $\alpha_{\mathrm{s} 1}-\mathrm{CN}(102-199)$. The scheme of casein degradation in Ragusano cheese is highly marked by the plasmin action, in agreement with the stretching temperature used during cheesemaking of about $50{ }^{\circ} \mathrm{C}$ and the presence of residual chymosin or cathepsin $\mathrm{D}$, which have already been shown to be active during long periods of aging in other types of hard cheeses.

Interestingly, $>90 \%$ of both caseins were hydrolyzed after 7 months of aging, indicating that the cheese protein network at this stage has dramatically changed. The initial protein network is finally composed of residual large casein fragments, maybe favored by the stretching step during the cheesemaking process. These fragments of high molecular weight were precipitated with the casein during the $\mathrm{pH} 4.6$ precipitation and were present in the centrifuge pellet during water extraction, confirming their presence as interacting material in the cheese matrix. This high percentage of casein degradation is in agreement with previous studies on Ragusano cheese regardless of the origin of the milk. ${ }^{11,30}$ In the literature, this case seems to be unique; in other cheeses with several months of ripening the level of residual $\beta$ and $\alpha_{\mathrm{s} 1}$-caseins remains always significant. Among pasta filata cheeses, Ragusano cheese is one of the most ripened; aging of mozzarella is a maximum of 2.5 months, and Caciocavallo Pugliese is aged from 2 to 6 months. In mozzarella cheeses, about $50 \%$ of the $\alpha_{\mathrm{s} 1}$-casein was degraded, and almost no degradation of $\beta$-casein was observed. ${ }^{36}$ Ragusano cheese, by having thermophilic lactic acid bacteria as the main starter flora $^{37,38}$ and long period of aging time, has to be considered to be close to long-termed ripened hard cheese such as Grana Padano and Parmigiano Reggiano. However, a lower decrease in both caseins was noted in Grana Padano: $26 \%$ decrease in $\beta$ casein $^{39}$ and $40 \%$ decrease in $\alpha_{\text {s1 }}$-casein ${ }^{40}$ after $4-7$ months of ripening. Even after 22 months of ripening, only $70 \%$ of both caseins was degraded. However, other studies on Grana Padano reported by Ferranti et al. ${ }^{41}$ mentioned a complete degradation of $\beta$-casein after 12 months of aging, whereas half of the $\alpha_{\mathrm{s} 1^{-}}$ casein remained. In Parmigiano Reggiano, around 15-20\% of $\beta$-casein was hydrolyzed at 8 months of aging and there was up to $50 \%$ degradation in 20 months. ${ }^{42}$ Proteolysis was found to stop after 24 months of ripening. ${ }^{43}$

Peptide Identification by Reversed Phase HPLC Coupled to Tandem Mass spectrometry. Up to now, among ripened pasta filata cheeses such as Caciocavallo and Kashkaval, only a few peptides have been identified. ${ }^{22}$ As most of the peptides were present in both experimental sets of cheeses (different altitude level raw milks) and proteolysis indices highly similar, as shown by equivalent TCA $\mathrm{SN} / \mathrm{pH} 4.6 \mathrm{SN}$ ratios, only the peptides identified in the experimental cheeses produced from high altitude level raw milk are presented. Figure 2 shows the peptide profile of the water soluble extract samples analyzed by RP HPLC coupled online with tandem mass spectrometry. This type of 


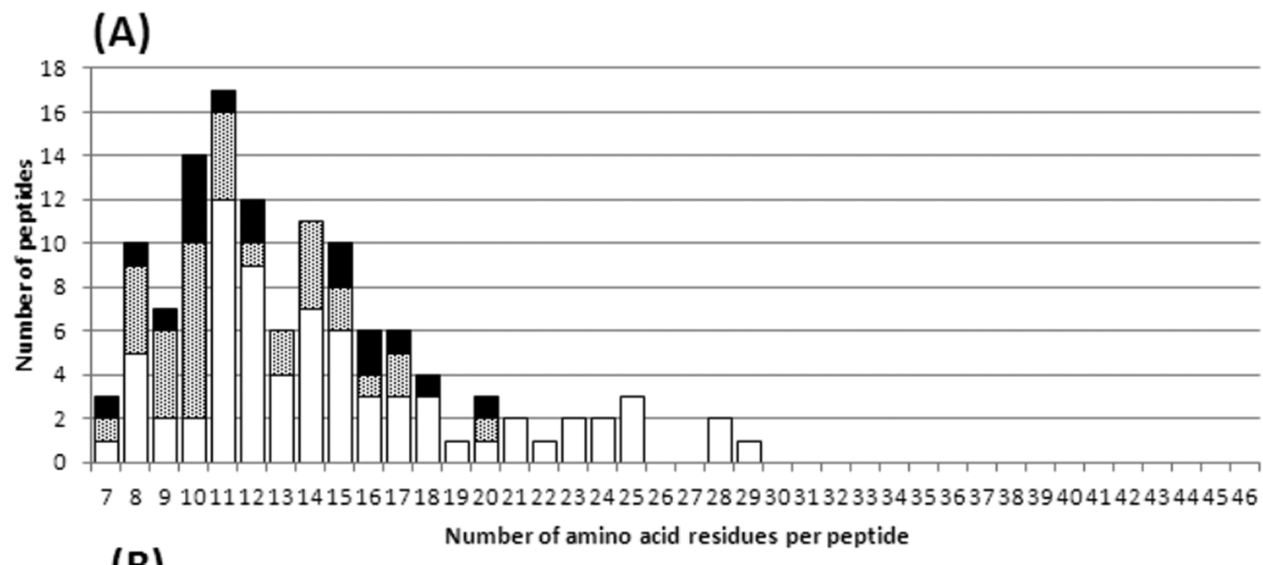

(B)

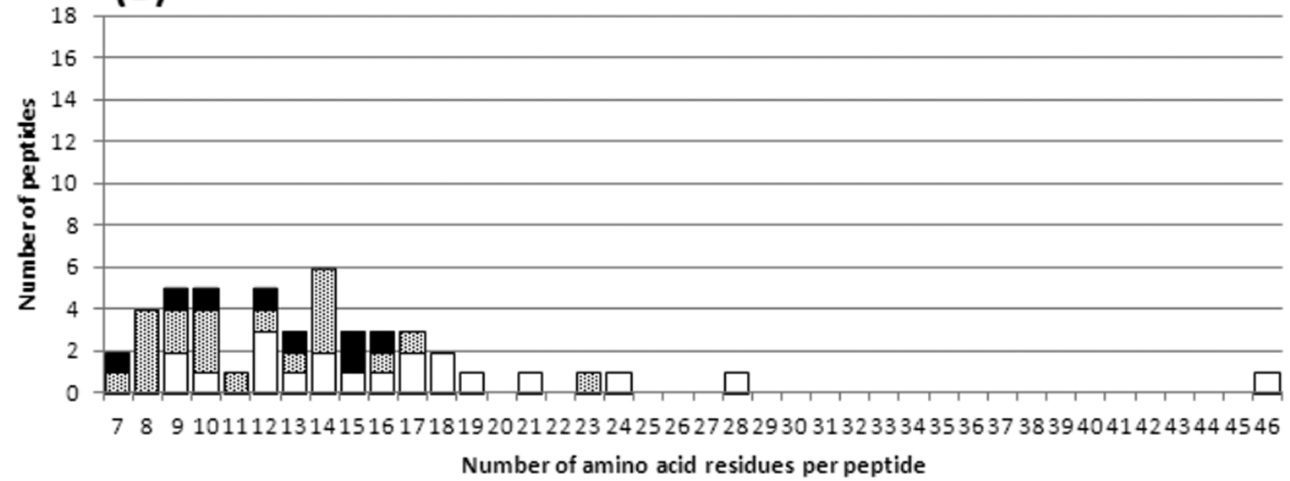

(C)

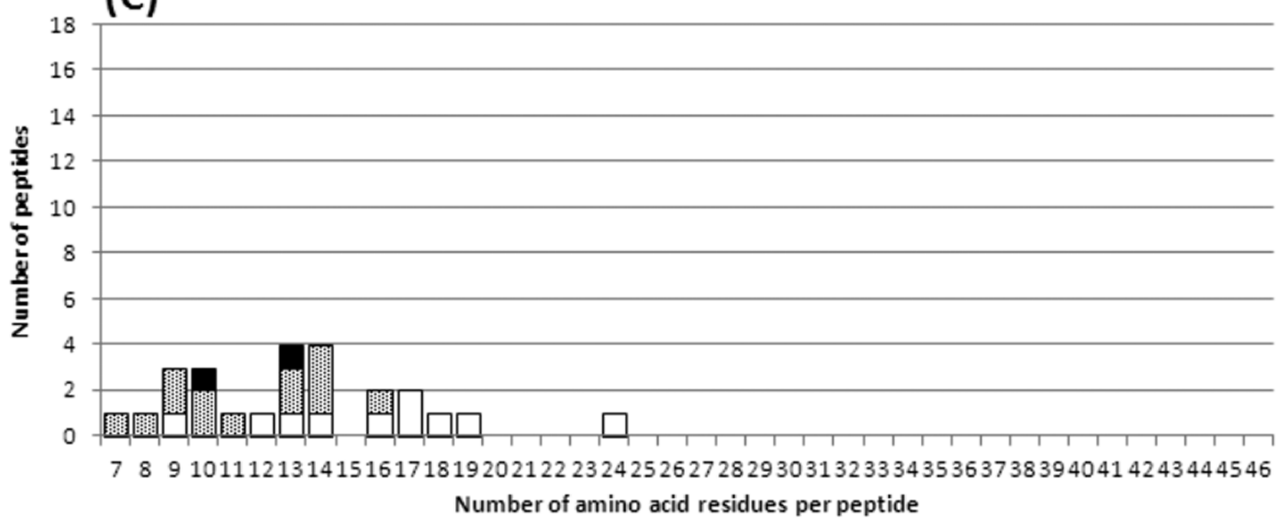

Figure 2. Numbers of peptides identified by reverse phase LC coupled online with ESI-MS/MS as a function of the size of the peptides present in Ragusano cheese from mountain milk after stretching (A) and after 4 months (B) and 7 months (C) of aging. The size of the identified peptides is

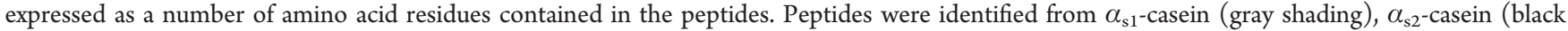
shading), and $\beta$-casein (no shading). The identified peptides from $\beta$-, $\alpha_{\mathrm{s} 1}$, and $\alpha_{\mathrm{s} 2}$-caseins are reported in Tables $2-4$, respectively.

extract was chosen to maintain the casein network as intact as possible. In that sense, it allows the identification of peptides that are not interacting with the casein network anymore. The number and size of the identified peptides from all caseins dramatically decreased from time 0 just after stretching to 7 months of aging. Although this representation is qualitative and corresponds to a partial view of the proteolysis, that is, peptides containing more than five amino acid residues, which are able to be ionized and detected by a mass spectrometer, it gives us a global view of the peptides released. Thus, we observed a simplification of RP HPLC profiles in terms of the number of identified peptides and centered between 6 and 18 amino acid residues regardless of the type of caseins. The progressive hydrolysis of large peptides is shown throughout ripening time and was coherent with increase of the observed TCA-soluble values and previous results. ${ }^{30}$

A general scheme of casein degradation throughout ripening is presented in Tables 2-4 From protein degradation in watersoluble extract of Ragusano cheese after stretching (at 0 days), 123 peptides were identified, 72 of which arose from $\beta$-casein, 34 from $\alpha_{\mathrm{s} 1}$-casein, and 17 from $\alpha_{\mathrm{s} 2}$-casein. The number of peptides identified dramatically decreased after 4 and 7 months of ripening, to 47 and 25 , respectively. At 4 months of aging, the 47 peptides identified are related to $\beta$-casein (i.e., 19) and $\alpha_{\mathrm{s} 1^{-}}$ casein (i.e., 20). At the end of ripening at 7 months, of 24 peptides identified, 9 were related to $\beta$-casein, 13 to $\alpha_{\mathrm{s} 1}$-casein, and 2 to $\alpha_{\mathrm{s} 2}$-casein. A more drastic decrease was shown in 
Table 2. Peptides Identified from $\boldsymbol{\beta}$-Casein in the Aqueous Extract of Ragusano Cheese Manufactured Using Mountain Milk, at 0, 4, and 7 Months of Ripening, by Reversed Phase Nano LC Coupled Online with ESI-QTOF MS/MS

\begin{tabular}{|c|c|c|c|c|c|c|c|}
\hline \multirow[b]{2}{*}{ peptide $^{b}$} & \multicolumn{2}{|c|}{ molecular mass, $M_{\mathrm{r}}(\mathrm{Da})$} & \multirow[b]{2}{*}{ score } & \multicolumn{3}{|c|}{ ripening time ${ }^{a}$ (months) } & \multirow[b]{2}{*}{ peptide sequence } \\
\hline & obsd & calcd $^{c}$ & & 0 & 4 & 7 & \\
\hline$\beta-\mathrm{CN}(1-14)$ & 1624.88 & 1624.83 & 39 & * & & & RELEELNVPGEIVE \\
\hline$\beta-\mathrm{CN}(1-16)$ & 1825.01 & 1824.95 & 46 & * & & & RELEELNVPGEIVESL \\
\hline$\beta-\mathrm{CN}(1-28)$ & 3476.60 & 3476.48 & 85 & * & & & RELEELNVPGEIVESLSSSEESITRINK \\
\hline$\beta-\mathrm{CN}(7-28) 4 \mathrm{P}$ & 2707.18 & 2707.08 & 49 & * & & & NVPGEIVESLSSSEESITRINK \\
\hline$\beta-\mathrm{CN}(11-28) 4 \mathrm{P}$ & 2339.97 & 2339.90 & 73 & & * & * & EIVESLSSSEESITRINK \\
\hline$\beta-\mathrm{CN}(12-28) 4 \mathrm{P}$ & 2210.87 & 2210.86 & 92 & & * & * & IVESLSSSEESITRINK \\
\hline$\beta-\mathrm{CN}(15-28) 3 \mathrm{P}$ & 1789.75 & 1789.69 & 52 & * & & & SLSSSEESITRINK \\
\hline$\beta-\mathrm{CN}(15-28) 4 \mathrm{P}$ & 1869.73 & 1869.66 & 63 & & * & & SLSSSEESITRINK \\
\hline$\beta-\mathrm{CN}(17-28) 3 \mathrm{P}$ & 1589.62 & 1589.58 & 30 & * & * & * & SSSEESITRINK \\
\hline$\beta-\mathrm{CN}(1-29)$ & 3604.75 & 3604.58 & 74 & * & & & RELEELNVPGEIVESLSSSEESITRINKK \\
\hline$\beta-\mathrm{CN}(29-39) 1 P$ & 1472.70 & 1472.65 & 44 & * & & & KIEKFQSEEQQ \\
\hline$\beta-\mathrm{CN}(32-39) 1 P$ & 1102.47 & 1102.43 & 37 & * & & & KFQSEEQQ \\
\hline$\beta-\mathrm{CN}(29-40) 1 P$ & 1600.77 & 1600.71 & 42 & * & & & KIEKFQSEEQQQ \\
\hline$\beta-\mathrm{CN}(32-40) 1 P$ & 1230.53 & 1230.49 & 43 & * & * & & KFQSEEQQQ \\
\hline$\beta-\mathrm{CN}(32-42) 1 P$ & 1460.62 & 1460.58 & 39 & * & & & KFQSEEQQQTE \\
\hline$\beta-\mathrm{CN}(29-43) 1 P$ & 1945.90 & 1945.83 & 31 & * & & & KIEKFQSEEQQQTED \\
\hline$\beta-\mathrm{CN}(32-43) 1 P$ & 1575.67 & 1575.61 & 32 & * & * & & KFQSEEQQQTED \\
\hline$\beta-\mathrm{CN}(33-43) 1 P$ & 1447.59 & 1447.51 & 39 & * & & & FQSEEQQQTED \\
\hline$\beta-\mathrm{CN}(29-45) 1 P$ & 2188.05 & 2187.96 & 39 & * & & & KIEKFQSEEQQQTEDEL \\
\hline$\beta-\mathrm{CN}(1-46) 5 \mathrm{P}$ & 5775.59 & 5775.47 & 39 & & * & & RELEELNVPGEIVESLSSSEESITRINKKIEKFQSEEQQQTEDELQ \\
\hline$\beta-\mathrm{CN}(28-46) 1 P$ & 2444.11 & 2444.11 & 33 & * & & & KKIEKFQSEEQQQTEDELQ \\
\hline$\beta-\mathrm{CN}(29-46) 1 P$ & 2316.09 & 2316.02 & 31 & * & & & KIEKFQSEEQQQTEDELQ \\
\hline$\beta-\mathrm{CN}(32-46) 1 P$ & 1945.85 & 1945.79 & 49 & * & & & KFQSEEQQQTEDELQ \\
\hline$\beta-\mathrm{CN}(29-47) 1 \mathrm{P}$ & 2431.14 & 2431.04 & 37 & * & & & KIEKFQSEEQQQTEDELQD \\
\hline$\beta-\mathrm{CN}(32-47) 1 P$ & 2060.89 & 2060.82 & 57 & * & & & KFQSEEQQQTEDELQD \\
\hline$\beta-\mathrm{CN}(29-51) 1 P$ & 2906.46 & 2906.33 & 33 & * & & & KIEKFQSEEQQQTEDELQDKIHP \\
\hline$\beta-\mathrm{CN}(45-51)$ & 849.50 & 849.47 & 31 & * & & & LQDKIHP \\
\hline$\beta-\mathrm{CN}(28-52) 1 P$ & 3181.62 & 3181.50 & 42 & * & & & KKIEKFQSEEQQQTEDELQDKIHPF \\
\hline$\beta-\mathrm{CN}(29-52) 1 P$ & 3053.47 & 3053.40 & 35 & * & * & * & KIEKFQSEEQQQTEDELQDKIHPF \\
\hline$\beta-\mathrm{CN}(30-52) 1 P$ & 2925.46 & 2925.31 & 30 & * & & & IEKFQSEEQQQTEDELQDKIHPF \\
\hline$\beta-\mathrm{CN}(32-52) 1 P$ & 2683.28 & 2683.18 & 50 & * & * & & KFQSEEQQQTEDELQDKIHPF \\
\hline$\beta-\mathrm{CN}(41-52)$ & 1470.76 & 1470.70 & 43 & * & * & & TEDELQDKIHPF \\
\hline$\beta-\mathrm{CN}(45-52)$ & 996.58 & 996.54 & 38 & * & & & LQDKIHPH \\
\hline$\beta-\mathrm{CN}(47-54)$ & 954.52 & 954.49 & 36 & * & & & DKIHPFAQ \\
\hline$\beta-\mathrm{CN}(29-56) 1 P$ & 3482.77 & 3482.59 & 36 & * & * & & KIEKFQSEEQQQTEDELQDKIHPFAQTQ \\
\hline$\beta-\mathrm{CN}(32-56) 1 P$ & 3111.53 & 3111.38 & 63 & * & & & KFQSEEQQQTEDELQDKIHPFAQTQ \\
\hline$\beta-\mathrm{CN}(43-56)$ & 1668.89 & 1668.81 & 52 & * & & & DELQDKIHPFAQTQ \\
\hline$\beta-\mathrm{CN}(44-56)$ & 1553.85 & 1553.78 & 50 & * & & & ELQDKIHPFAQTQ \\
\hline$\beta-\mathrm{CN}(45-56)$ & 1424.84 & 1424.74 & 54 & * & & & LQDKIHPFAQTQ \\
\hline$\beta-\mathrm{CN}(46-56)$ & 1311.74 & 1311.66 & 40 & * & & & QDKIHPFAQTQ \\
\hline$\beta-\mathrm{CN}(47-57)$ & 1270.67 & 1270.63 & 47 & * & & & DKIHPFAQTQS \\
\hline$\beta-\mathrm{CN}(94-105)$ & 1259.74 & 1259.69 & 67 & * & & & GVSKVKEAMAPK + oxidation $(\mathrm{M})$ \\
\hline$\beta-\mathrm{CN}(97-105)$ & 1000.60 & 1000.57 & 38 & * & * & * & KVKEAMAPK \\
\hline$\beta-\mathrm{CN}(98-105)$ & 872.51 & 872.48 & 59 & * & & & VKEAMAPK \\
\hline$\beta-\mathrm{CN}(103-113)$ & 1308.73 & 1308.70 & 50 & * & & & APKHKEMPFPК \\
\hline$\beta-\mathrm{CN}(96-119)$ & 2814.64 & 2814.46 & 34 & * & & & SKVKEAMAPKHKEMPFPKYPVEPF \\
\hline$\beta-\mathrm{CN}(100-119)$ & 2372.24 & 2372.17 & 34 & * & & & ЕАMAPКHKEMPFPKYPVEPF \\
\hline$\beta-\mathrm{CN}(106-119)$ & 1744.93 & 1744.86 & 38 & * & & & HKEMPFPKYPVEPF \\
\hline$\beta-\mathrm{CN}(107-119)$ & 1607.91 & 1607.91 & 42 & * & & & KEMPFPKYPVEPF \\
\hline$\beta-\mathrm{CN}(109-119)$ & 1350.71 & 1350.67 & 34 & * & & & MPFPKYPVEPF \\
\hline$\beta-\mathrm{CN}(103-123)$ & 2486.31 & 2486.23 & 40 & * & & & APKHKEMPFPKYPVEPFTESQ \\
\hline
\end{tabular}


Table 2. Continued

\begin{tabular}{|c|c|c|c|c|c|c|c|}
\hline \multirow[b]{2}{*}{ peptide $^{b}$} & \multicolumn{2}{|c|}{ molecular mass, $M_{\mathrm{r}}(\mathrm{Da})$} & \multirow[b]{2}{*}{ score } & \multicolumn{3}{|c|}{ ripening time ${ }^{a}$ (months) } & \multirow[b]{2}{*}{ peptide sequence } \\
\hline & obsd & calcd $^{c}$ & & 0 & 4 & 7 & \\
\hline$\beta-\mathrm{CN}(106-123)$ & 2190.08 & 2190.05 & 53 & * & & & HKEMPFPKYPVEPFTESQ \\
\hline$\beta-\mathrm{CN}(144-154)$ & 1281.63 & 1281.63 & 34 & * & & & MHQPHQPLPPT \\
\hline$\beta-\mathrm{CN}(145-154)$ & 1150.63 & 1150.59 & 34 & * & & & HQPHQPLPPT \\
\hline$\beta-\mathrm{CN}(166-176)$ & 1209.75 & 1209.71 & 50 & * & & & SQSKVLPVPQK \\
\hline$\beta-\mathrm{CN}(166-182)$ & 1865.10 & 1865.04 & 50 & * & & & SQSKVLPVPQKAVPYPQ \\
\hline$\beta-\mathrm{CN}(168-182)$ & 1650.00 & 1649.95 & 42 & * & & & SKVLPVPQKAVPYPQ \\
\hline$\beta-\mathrm{CN}(171-182)$ & 1335.81 & 1335.76 & 44 & * & & & LPVPQKAVPYPQ \\
\hline$\beta-\mathrm{CN}(176-189)$ & 1612.87 & 1672.84 & 41 & * & & & KAVPYPQRDMPIQA \\
\hline$\beta-\mathrm{CN}(182-189)$ & 957.50 & 957.47 & 31 & * & & & QRDMPIQA \\
\hline$\beta-\mathrm{CN}(166-190)$ & 2823.64 & 2823.51 & 42 & * & & & SQSKVLPVPQKAVPYPQRDMPIQAF \\
\hline$\beta-\mathrm{CN}(178-190)$ & 1560.85 & 1560.78 & 32 & * & & & VPYPQRDMPIQAF \\
\hline$\beta-\mathrm{CN}(183-192)$ & 1202.60 & 1202.65 & 47 & & * & & RDMPIQAFLL \\
\hline$\beta-\mathrm{CN}(194-202)$ & 993.60 & 993.56 & 40 & * & & & QEPVLGPVR \\
\hline$\beta-\mathrm{CN}(193-204)$ & 1310.73 & 1310.70 & 57 & * & & & YQEPVLGPVRGP \\
\hline$\beta-\mathrm{CN}(194-204)$ & 1147.66 & 1147.63 & 30 & * & & & QEPVLGPVRGP \\
\hline$\beta-\mathrm{CN}(195-204)$ & 1019.56 & 1019.58 & 50 & * & & & EPVLGPVRGP \\
\hline$\beta-\mathrm{CN}(193-206)$ & 1554.86 & 1554.82 & 46 & * & * & * & YQEPVLGPVRGPFP \\
\hline$\beta-\mathrm{CN}(194-206)$ & 1391.79 & 1391.76 & 56 & * & * & * & QEPVLGPVRGPFP \\
\hline$\beta-\mathrm{CN}(195-206)$ & 1263.76 & 1263.70 & 41 & * & & & EPVLGPVRGPFP \\
\hline$\beta-\mathrm{CN}(196-206)$ & 1134.71 & 1134.65 & 47 & * & & & PVLGPVRGPFP \\
\hline$\beta-\mathrm{CN}(193-207)$ & 1668.02 & 1667.90 & 47 & * & * & & YQEPVLGPVRGPFPI \\
\hline$\beta-\mathrm{CN}(194-207)$ & 1504.95 & 1504.84 & 50 & * & & & QEPVLGPVRGPFPI \\
\hline$\beta-\mathrm{CN}(193-208)$ & 1780.97 & 1780.99 & 42 & & & * & YQEPVLGPVRGPFPII \\
\hline$\beta-\mathrm{CN}(194-208)$ & 1618.00 & 1617.92 & 40 & * & & & QEPVLGPVRGPFPII \\
\hline$\beta-\mathrm{CN}(191-209)$ & 2106.19 & 2106.22 & 33 & & * & * & LLYQEPVLGPVRGPFPIIV \\
\hline$\beta-\mathrm{CN}(192-209)$ & 1993.16 & 1993.14 & 38 & & * & & LYQEPVLGPVRGPFPIIV \\
\hline$\beta-\mathrm{CN}(193-209)$ & 1880.10 & 1880.06 & 31 & * & * & * & YQEPVLGPVRGPFPIIV \\
\hline$\beta-\mathrm{CN}(194-209)$ & 1717.08 & 1716.99 & 38 & * & * & & QEPVLGPVRGPFPIIV \\
\hline$\beta-\mathrm{CN}(195-209)$ & 1589.00 & 1588.93 & 36 & * & & & EPVLGPVRGPFPIIV \\
\hline
\end{tabular}

${ }^{a}$ An asterisk indicates the presence of identified peptides at 0,4 , and 7 months of ripening period. ${ }^{b}$ Peptides written in bold correspond to phosphopeptides, and the number of phosphorylated residues present in the peptides is mentioned as $1 \mathrm{P}, 2 \mathrm{P}, 3 \mathrm{P}, 4 \mathrm{P}$, or $5 \mathrm{P}$. ${ }^{c}$ Value of molecular mass of the protein from the SwissProt/Uniprot database.

Ragusano cheese at 7 months than in Grana Padano at 38 months of ripening, in which 45 peptides were still identified in the $3 \mathrm{kDa}$ fraction of soluble peptides. ${ }^{41}$

The main cleavage sites for $\beta$-, $\alpha_{\mathrm{s}^{-}}$, and $\alpha_{\mathrm{s} 2}$-caseins arose from the well-known action of plasmin and residual chymosin or cathepsin D. A more detailed view of the identified peptides is presented below.

$\beta$-Casein-Derived Peptides. As expected, the fragment $\beta$ $\mathrm{CN}(1-28)$ was found in the 0 month cheese fraction concomitantly with the peptide $\beta$ - $\mathrm{CN}(29-209)\left(\gamma_{1}-\mathrm{CN}\right)$ shown in ureaPAGE, resulting from the plasmin action. The fragment $\beta$ $\mathrm{CN}(1-28)$ was rapidly cleaved, because in this fraction other smaller derived peptides such as $\beta-\mathrm{CN}(7-28), \beta-\mathrm{CN}(11-28, \beta$ $\mathrm{CN}(15-28)$, and $\beta-\mathrm{CN}(17-28)$ were produced. The presence of these peptides suggested the action of CEP from lactic acid bacteria such as Lactococcus. lactis ${ }^{44,45}$ or lactobacilli such as Lactobacillus helveticus ${ }^{46}$ and $L b$. delbrueckii subsp. lactis, ${ }^{47}$ species present in the complex ecosystem of the Ragusano tina ${ }^{37,38}$ in the early period of aging.

Most of the identified peptides were produced in the cheese right after stretching throughout the sequence of the $\beta$-casein and further degraded during ripening to form smaller ones found at 7 months (Table 3 ). The identified peptides were observed throughout the $\beta$-casein sequence by various proteinases from milk and from microflora and bacterial peptidases, as early as the curd step. Gradually, peptides were identified only in the $\mathrm{N}$ - and $\mathrm{C}$-terminal ends of the $\beta$-casein. Surprisingly, very few identified peptides remained at the end of the aging time in contrast to Parmigiano Reggiano, ${ }^{20,21}$ Cheddar, ${ }^{48,49}$ and Emmental ${ }^{15}$ cheeses.Thus, $\beta$-CN $(11 / 12 / 17-28), \beta-\mathrm{CN}(29-52), \beta$-CN(97-105), $\beta-\mathrm{CN}(193 / 194-206)$, and $\beta-\mathrm{CN}(193-209)$ accumulated until the end of ripening. Peptides $\beta-\mathrm{CN}(11 / 12 / 15 /$ $17-28)$ and $\beta-\mathrm{CN}(29-52)$ contained phosphoseryl residues. The level of phosphorylation varied as shown for the peptide $\beta$ $\mathrm{CN}(15-28)$, which initially possesses four phosphorylated serine residues. This peptide lost one phosphate group, rendering possible the degradation to the next three phosphorylated residues, that is, $\beta$-CN $(17-28)$, identified even after 7 months of aging, which confers resistance to their further hydrolysis by bacterial peptidases. ${ }^{50}$ Only the peptides that possess a cluster of three amino acid residues were already shown to resist further degradation by bacterial aminopeptidase. ${ }^{50}$ This was confirmed by the degradation of these peptides beyond their phosphoserine residue. Such phosphopeptides through their binding to calcium 
Table 3. Peptides Identified from $\alpha_{s 1}$-Casein in the Aqueous Extract of Ragusano Cheese Manufactured Using Mountain Milk, at 0, 4, and 7 Months of Ripening, by Reversed Phase Nano LC Coupled Online with ESI-QTOF MS/MS

\begin{tabular}{|c|c|c|c|c|c|c|c|}
\hline \multirow[b]{2}{*}{ peptide $^{b}$} & \multicolumn{2}{|c|}{ molecular mass, $M_{\mathrm{r}}(\mathrm{Da})$} & \multirow[b]{2}{*}{ score } & \multicolumn{3}{|c|}{ ripening time ${ }^{a}$ (months) } & \multirow[b]{2}{*}{ sequence } \\
\hline & obsd & calcd $^{c}$ & & 0 & 4 & 7 & \\
\hline$\alpha_{\mathrm{s} 1}-\mathrm{CN}(1-9)$ & 1139.71 & 1139.67 & 38 & * & * & * & RPKHPIKHQ \\
\hline$\alpha_{\mathrm{s} 1}-\mathrm{CN}(2-9)$ & 983.55 & 983.57 & 39 & & * & & PKHPIKHQ \\
\hline$\alpha_{\mathrm{s} 1}-\mathrm{CN}(1-14)$ & 1663.79 & 1663.93 & 71 & * & * & & RPKHPIKHQGLPQE \\
\hline$\alpha_{\mathrm{s} 1}-\mathrm{CN}(2-14)$ & 1507.86 & 1507.83 & 43 & & * & * & PKHPIKHQGLPQE \\
\hline$\alpha_{\mathrm{s} 1}-\mathrm{CN}(1-17)$ & 1990.21 & 1990.12 & 36 & * & * & & RPKHPIKHQGLPQEVLN \\
\hline$\alpha_{\mathrm{s} 1}-\mathrm{CN}(7-17)$ & 1261.72 & 1261.68 & 34 & * & & & KHQGLPQEVLN \\
\hline$\alpha_{\mathrm{s} 1}-\mathrm{CN}(8-17)$ & 1133.63 & 1133.58 & 71 & * & & & HQGLPQEVLN \\
\hline$\alpha_{\mathrm{s} 1}-\mathrm{CN}(1-23)$ & 2762.57 & 2762.55 & 48 & & * & & RPKHPIKHQGLPQEVLNENLLRF \\
\hline$\alpha_{\mathrm{s} 1}-\mathrm{CN}(10-23)$ & 1640.93 & 1640.89 & 65 & & * & * & GLPQEVLNENLLRF \\
\hline$\alpha_{\mathrm{s} 1}-\mathrm{CN}(14-23)$ & 1245.69 & 1245.67 & 42 & * & * & * & EVLNENLLRF \\
\hline$\alpha_{\mathrm{s} 1^{-} \mathrm{CN}}(15-23)$ & 1116.68 & 1116.63 & 66 & * & * & * & VLNENLLRF \\
\hline$\alpha_{\mathrm{s} 1}-\mathrm{CN}(16-23)$ & 1017.59 & 1017.56 & 59 & * & * & & LNENLLRF \\
\hline$\alpha_{\mathrm{s} 1}-\mathrm{CN}(17-23)$ & 904.49 & 904.48 & 47 & * & * & * & NENL LRF \\
\hline$\alpha_{\mathrm{s} 1}-\mathrm{CN}(25-34)$ & 1089.65 & 1089.59 & 39 & * & * & & VAPFPEVFGK \\
\hline$\alpha_{\mathrm{s} 1}-\mathrm{CN}(24-36)$ & 1493.83 & 1493.79 & 70 & * & & & FVAPFPEVFGKEK \\
\hline$\alpha_{\mathrm{s} 1}-\mathrm{CN}(24-37)$ & 1592.90 & 1592.86 & 36 & * & * & * & FVAPFPEVFGKEKV \\
\hline$\alpha_{\mathrm{s} 1}-\mathrm{CN}(25-37)$ & 1445.87 & 1445.79 & 32 & * & & & VAPFPEVFGKEKV \\
\hline$\alpha_{\mathrm{s} 1}-\mathrm{CN}(26-37)$ & 1346.77 & 1346.72 & 51 & * & & & APFPEVFGKEKV \\
\hline$\alpha_{\mathrm{s} 1}-\mathrm{CN}(30-37)$ & 934.54 & 934.51 & 39 & * & & & EVFGKEKV \\
\hline$\alpha_{\mathrm{s} 1}-\mathrm{CN}(24-38)$ & 1707.03 & 1706.90 & 50 & * & & & FVAPFPEVFGKEKVN \\
\hline$\alpha_{\mathrm{s} 1^{-} \mathrm{CN}}(25-38)$ & 1559.77 & 1559.83 & 49 & * & & & VAPFPEVFGKEKVN \\
\hline$\alpha_{\mathrm{s} 1}-\mathrm{CN}(24-40)$ & 1949.13 & 1949.03 & 42 & * & & & FVAPFPEVFGKEKVNEL \\
\hline$\alpha_{\mathrm{s} 1}-\mathrm{CN}(25-40)$ & 1802.01 & 1801.96 & 38 & * & & & VAPFPEVFGKEKVNEL \\
\hline$\alpha_{\mathrm{s} 1}-\mathrm{CN}(31-40)$ & 1161.70 & 1161.64 & 39 & * & & & VFGKEKVNEL \\
\hline$\alpha_{\mathrm{s} 1}-\mathrm{CN}(33-42)$ & 1130.66 & 1130.63 & 48 & * & & & GKEKVNELSK \\
\hline$\alpha_{\mathrm{s} 1}-\mathrm{CN}(24-43)$ & 2279.30 & 2279.18 & 35 & * & & & FVAPFPEVFGKEKVNELSKD \\
\hline$\alpha_{s 1}-\mathrm{CN}(41-52) 2 \mathrm{P}$ & 1454.54 & 1454.49 & 37 & & * & & SKDIGSESTEDQ \\
\hline$\alpha_{s 1}-\mathrm{CN}(41-54) 2 \mathrm{P}$ & 1656.50 & 1656.56 & 46 & & * & * & SKDIGSESTEDQAM \\
\hline$\alpha_{\mathrm{s1}}-\mathrm{CN}(41-56) 2 \mathrm{P}$ & 1900.73 & 1900.63 & 41 & & * & * & SKDIGSESTEDQAMED \\
\hline$\alpha_{s 1}-\mathrm{CN}(42-56) 2 \mathrm{P}$ & 1813.70 & 1813.60 & 35 & & & * & KDIGSESTEDQAMED \\
\hline$\alpha_{s 1}-\mathrm{CN}(75-82) 1 \mathrm{P}$ & 1047.49 & 1047.47 & 36 & & * & * & SVEQKHIQ \\
\hline$\alpha_{s 1}-\mathrm{CN}(75-84) 1 \mathrm{P}$ & 1304.68 & 1304.61 & 28 & * & * & & SVEQKHIQKE \\
\hline$\alpha_{\mathrm{s} 1}-\mathrm{CN}(80-89)$ & 1180.61 & 1180.57 & 30 & * & & & HIQKEDVPSE \\
\hline$\alpha_{s 1}-\mathrm{CN}(80-90)$ & 1336.75 & 1336.67 & 47 & * & & * & HIQKEDVPSER \\
\hline$\alpha_{\mathrm{s} 1}-\mathrm{CN}(83-90)$ & 958.50 & 958.47 & 55 & * & * & & KEDVPSER \\
\hline$\alpha_{\mathrm{s} 1}-\mathrm{CN}(83-92)$ & 1234.64 & 1234.62 & 41 & * & & * & KEDVPSERYL \\
\hline$\alpha_{\mathrm{s} 1}-\mathrm{CN}(83-93)$ & 1291.68 & 1291.64 & 45 & * & * & & KEDVPSERYLG \\
\hline$\alpha_{s 1}-\mathrm{CN}(103-117) 1 \mathrm{P}$ & 1793.85 & 1793.90 & 38 & * & & & KYKVPQLEIVPNSAE \\
\hline$\alpha_{s 1}-\mathrm{CN}(104-117) 1 \mathrm{P}$ & 1665.89 & 1665.80 & 34 & * & & & YKVPQLEIVPNSAE \\
\hline$\alpha_{s 1}-\mathrm{CN}(115-123) 1 \mathrm{P}$ & 1138.50 & 1138.45 & 34 & * & & & SAEERLHSM \\
\hline$\alpha_{\mathrm{s} 1}-\mathrm{CN}(123-130)$ & 912.47 & 912.45 & 42 & * & & & MKEGIHAQ \\
\hline$\alpha_{\mathrm{s} 1}-\mathrm{CN}(132-140)$ & 1014.57 & 1014.52 & 45 & * & & & KEPMIGVNQ \\
\hline$\alpha_{\mathrm{s} 1}-\mathrm{CN}(132-142)$ & 1256.67 & 1256.64 & 54 & * & & & KEPMIGVNQEL \\
\hline
\end{tabular}

${ }^{a}$ An asterisk indicates the presence of identified peptides at 0,4 , and 7 months of ripening period. ${ }^{b}$ Peptides written in bold correspond to phosphopeptides, and the number of phosphorylated residues present in the peptides is mentioned as $1 \mathrm{P}$ or $2 \mathrm{P} .^{c}$ Value of molecular mass of the protein from the SwissProt/Uniprot database.

are prone to be mineral-carrying peptides in the digestive tract and protective against caries. ${ }^{51,52}$

With regard to the $\mathrm{C}$-terminal end of the casein, one pool of peptides containing $\beta$ - $\mathrm{CN}(193-209)$ is present throughout aging. $\beta-\mathrm{CN}(193-209)$ is considered to be an immunomodulating peptide. ${ }^{51}$ It has to be noted that this peptide is one of the peptides present in most cheeses regardless of the technology used, certainly due to the action of various enzymes on the bond $\mathrm{Leu}_{192}-\mathrm{Phe}_{193}$, such as chymosin, cathepsin D, and most of the cell wall proteinases of lactic acid bacteria. 
Table 4. Peptides Identified from $\alpha_{\mathrm{s2} 2}$-Casein in the Aqueous Extract of Ragusano Cheese Manufactured Using Mountain Milk, at 0, 4, and 7 Months of Ripening, by Reversed Phase Nano LC Coupled Online with ESI-QTOF MS/MS

\begin{tabular}{|c|c|c|c|c|c|c|c|}
\hline \multirow[b]{2}{*}{ peptide $^{b}$} & \multicolumn{2}{|c|}{ molecular mass, $M_{\mathrm{r}}(\mathrm{Da})$} & \multirow[b]{2}{*}{ score } & \multicolumn{3}{|c|}{ ripening time $e^{a}$ (months) } & \multirow[b]{2}{*}{ sequence } \\
\hline & obsd & calcd $^{c}$ & & 0 & 4 & 7 & \\
\hline$\alpha_{\mathrm{s} 2}-\mathrm{CN}(1-18) 4 \mathrm{P}$ & 2353.82 & 2353.79 & 39 & $*$ & & & KNTMEHVSSSEESIISQE \\
\hline$\alpha_{\mathrm{s} 2}-\mathrm{CN}(1-21) 4 \mathrm{P}$ & 2746.10 & 2745.99 & 48 & * & & & KNTMEHVSSSEESIISQETYK \\
\hline$\alpha_{\mathrm{s} 2}-\mathrm{CN}(6-21)$ & 2142.80 & 2142.72 & 64 & * & & & HVSSSEESIISQETYK \\
\hline$\alpha_{\mathrm{s} 2}-\mathrm{CN}(100-114)$ & 1812.01 & 1811.97 & 38 & * & * & & YQGPIVLNPWDQVKR \\
\hline$\alpha_{\mathrm{s} 2}-\mathrm{CN}(105-114)$ & 1253.71 & 1253.69 & 37 & * & & & VLNPWDQVKR \\
\hline$\alpha_{\mathrm{s} 2}-\mathrm{CN}(100-115)$ & 1926.10 & 1926.01 & 30 & $*$ & * & & YQGPIVLNPWDQVKRN \\
\hline$\alpha_{\mathrm{s} 2}-\mathrm{CN}(101-115)$ & 1763.01 & 1762.95 & 31 & $*$ & * & & QGPIVLNPWDQVKRN \\
\hline$\alpha_{\mathrm{s} 2}-\mathrm{CN}(126-138) 2 \mathrm{P}$ & 1639.67 & 1639.64 & 45 & & & * & EQLSTSEENSKKT \\
\hline$\alpha_{\mathrm{s} 2}-\mathrm{CN}(141-150) 1 \mathrm{P}$ & 1278.62 & 1278.56 & 50 & * & & & MSTEVFTKK \\
\hline$\alpha_{\mathrm{s} 2}-\mathrm{CN}(143-150) 1 \mathrm{P}$ & 1018.51 & 1018.47 & 53 & $*$ & & & STEVFTKK \\
\hline$\alpha_{\mathrm{s} 2}-\mathrm{CN}(148-157)$ & 1205.67 & 1205.65 & 29 & $*$ & & & TKKTKLTEEE \\
\hline$\alpha_{\mathrm{s} 2}-\mathrm{CN}(146-162)$ & 2077.26 & 2077.15 & 34 & * & & & VFTKKTKLTEEEKNRLN \\
\hline$\alpha_{\mathrm{s} 2}-\mathrm{CN}(150-162)$ & 1601.90 & 1601.87 & 35 & & * & & KTKLTEEEKNRLN \\
\hline$\alpha_{\mathrm{s} 2}-\mathrm{CN}(151-162)$ & 1473.81 & 1473.78 & 29 & * & * & & TKLTEEEKNRLN \\
\hline$\alpha_{\mathrm{s} 2}-\mathrm{CN}(152-162)$ & 1372.76 & 1372.73 & 29 & * & & & KLTEEEKNRLN \\
\hline$\alpha_{\mathrm{s} 2}-\mathrm{CN}(153-162)$ & 1244.68 & 1244.64 & 38 & $*$ & * & * & LTEEEKNRLN \\
\hline$\alpha_{\mathrm{s} 2}-\mathrm{CN}(191-197)$ & 895.55 & 895.53 & 33 & * & * & & KPWIQPK \\
\hline$\alpha_{\mathrm{s} 2}-\mathrm{CN}(191-199)$ & 1124.70 & 1124.67 & 55 & $*$ & * & & KPWIQPKTK \\
\hline$\alpha_{\mathrm{s} 2}-\mathrm{CN}(191-202)$ & 1433.91 & 1433.88 & 81 & $*$ & & & KPWIQPKTKVIP \\
\hline
\end{tabular}

${ }^{a}$ An asterisk indicates the presence of identified peptides at 0,4 , and 7 months of ripening period. ${ }^{b}$ Peptides written in bold correspond to phosphopeptides, and the number of phosphorylated residues present in the peptides is mentioned as $1 \mathrm{P}, 2 \mathrm{P}, 3 \mathrm{P}$, or $4 \mathrm{P}$. ${ }^{c}$ Value of molecular mass of the protein from the SwissProt/Uniprot database.

$\alpha_{51}$-Casein-Derived Peptides. As for $\beta$-casein, peptide $\alpha_{\mathrm{s} 1^{-}}$ $\mathrm{CN}(1-23)$, resulting from hydrolysis by chymosin and thereafter by cathepsin $\mathrm{D}$, less thermolabile than chymosin, was also already degraded in cheese after stretching. The following peptide sequences were found: $\alpha_{s 1}-\mathrm{CN}(14 / 15 / 16 / 17-23)$ as well as $\alpha_{\mathrm{s} 1}-\mathrm{CN}(24 / 36 / 37 / 38 / 40 / 43)$. The presence of the $\alpha_{\mathrm{s} 1^{-}}$ $\mathrm{CN}(1-9), \quad \alpha_{s 1}-\mathrm{CN}(1-14)$, and $\alpha_{s 1}-\mathrm{CN}(15-23)$ fragments reinforces the fact that CEP from lactic acid bacteria are active in Ragusano cheese: from Lc. lactis, ${ }^{53} \mathrm{Lb}$. helveticus, ${ }^{46}$ and/or $L b$. delbrueckii subsp. lactis. ${ }^{47}$ The set of $\alpha_{\mathrm{s} 1}-\mathrm{CN}(14 / 15 / 16 / 17-23)$ also represents the aminopeptidase activity with broad specificity, and the release of $\alpha_{\mathrm{s} 1}-\mathrm{CN}(24 / 36 / 37 / 38 / 40 / 43), \alpha_{\mathrm{s} 1}-\mathrm{CN}$ $(25-34 / 37 / 38 / 40)$ reflected the activity of carboxypeptidases. ${ }^{16,54}$ Part of the $\alpha_{\mathrm{s} 1}$-casein sequence was degraded by the proteolytic enzymes, in agreement with a lesser accessibility in the cheese, notably of the central region (between residues 56 and 75) and the C-terminal end (between residues 140 and 190). ${ }^{46}$ Reinforcing this idea was our observation of the presence of phosphorylated peptides containing from 1 to 2 phosphoserine residues in contrast

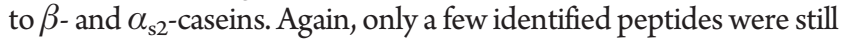
present at the end of aging and distributed between residues $\operatorname{Arg}_{1}$ and $\mathrm{Tyr}_{94}$. Among them, $\alpha_{\mathrm{s} 1}-\mathrm{CN}(1-9)$ has been described as being potentially antihypertensive.

$\alpha_{s 2}$-Casein-Derived Peptides. With regard to $\alpha_{\mathrm{s} 2}$-casein, the fragment $\alpha_{\mathrm{s} 2}-\mathrm{CN}(1-21)$ is released by the action of plasmin, which cleaves specifically the $\mathrm{Lys}_{21}-\mathrm{Gln}_{22}$ bond. ${ }^{55}$ Less information is available in the literature on the action of various endo- and exopeptidases on this casein that can lead to $\alpha_{\mathrm{s} 2}-\mathrm{CN}(5 / 6-21)$, likely because the lower concentration of this casein in milk makes its purification difficult. Phosphopeptides were the main components isolated from the soluble fraction in the
N-terminal zone, each containing four phosphate groups. Among the two identified peptides left at the end of aging, one was a phosphopeptide $\alpha_{\mathrm{s} 2}-\mathrm{CN}(126-138) 2 \mathrm{P}$ and the other the $\alpha_{\mathrm{s}^{-}}$ $\mathrm{CN}(153-162)$. The fragment $\alpha_{\mathrm{s} 2}-\mathrm{CN}(100-115)$ arose from the action of cathepsin $\mathrm{D}$, which has been reported to cleave $\alpha_{\mathrm{s} 2^{-}}$ casein at $\mathrm{Leu}_{99}-\mathrm{Tyr}_{100}$, ${ }^{56}$ and lactococcal cell-envelope proteinase, which has been reported to cleave $\alpha_{\mathrm{s} 2}-\mathrm{CN}$ at $\mathrm{Leu}_{115}-\mathrm{Tyr}_{116}$ in Cheddar cheese. ${ }^{2}$ This fragment was found to be further hydrolyzed at both $\mathrm{C}$ - and $\mathrm{N}$-terminal ends, forming three fragments, $\alpha_{\mathrm{s} 2}-\mathrm{CN}(100-114), \alpha_{\mathrm{s} 2}-\mathrm{CN}(101-114)$, and $\alpha_{\mathrm{s} 2}-\mathrm{CN}-$ (101-115), with $\operatorname{Arg}_{114}-$ Asn $_{115}$ cleaved by plasmin bond. ${ }^{55}$

Ragusano cheese produced in Sicily is one of the very rare pasta filata cheeses that is ripened for several months. Two original features were observed in the proteolysis scheme of this cheese. Less than $10 \%$ residual $\beta$ - and $\alpha_{\mathrm{s}}$-caseins remained intact after 7 months, indicating that the cheese protein network is based on large casein fragments tightly associated. Such a peculiar microstructure could be related to the traditional cheesemaking technology (use of natural rennet, temperature, and $\mathrm{pH}$ of all pasta filata processes) and should be further explored. In parallel, the number of identified soluble peptides dramatically decreased from 123 at day 0 , to 47 and 25 , respectively, after 4 and 7 months of ripening. This means that cheese large soluble peptides are almost integrally hydrolyzed by peptidases of lactic acid bacteria, which is a unique case in the literature. This was supported by the high increase $>82 \%$ of the TCA SN/pH 4.6 SN ratio. The data for other cheese varieties for which proteolysis was observed with a similar mass spectrometry approach highlighted rather a continuous balance during ripening between large peptide production and their subsequent hydrolysis into small peptides and free amino acids. The results presented here are obviously 
different. Apparently, large soluble peptides are produced early from caseins by residual rennet, plasmin, and cathepsin $\mathrm{D}$, and then this production stopped; these soluble peptides are almost completely hydrolyzed during ripening. Again, the particular network microstructure due to the Ragusano technology could explain this phenomenon: the accessibility to proteolytic enzymes could be impaired by the strong interactions between the large casein fragments constituting the network. Whatever the explanation, the extensive hydrolysis of soluble peptides is likely positive for the subsequent flavor compounds through amino acid catabolism. Ragusano indeed exhibited many varied flavor compounds. ${ }^{9}$ Among the few residual peptides after 7 months of ripening, bioactive peptides were found, that is, mineral carrier, antihypertensive, and immunomodulating peptides. Phosphopeptides from the $\mathrm{N}$-terminal part of the $\beta$-, $\alpha_{\mathrm{s} 1^{-}}$, and $\alpha_{\mathrm{s} 2^{-}}$-caseins were also present, but their intrinsic resistance to peptidases of lactic acid bacteria was already described, ${ }^{50}$ explaining their presence in the soluble phase of many long-term-ripened cheeses (e.g., Emmental, Grana Padano). Some peptides are nevertheless common to other technologies, such as $\alpha_{\mathrm{s} 1}-\mathrm{CN}(1-8), \alpha_{\mathrm{s} 1}-\mathrm{CN}(1-9)$, $\alpha_{\mathrm{s} 1}-\mathrm{CN}(1-14), \alpha_{\mathrm{s} 1}-\mathrm{CN}(1-15), \alpha_{\mathrm{s} 1}-\mathrm{CN}(1-17)$, and $\alpha_{\mathrm{s} 1}-\mathrm{CN}-$ $(4-14)$, reflecting the action of the very close lactic acid bacteria, notably lactobacilli and streptococci as in Emmental cheese, ${ }^{15}$ or $\beta$ - $\mathrm{CN}(1-28), \beta-\mathrm{CN}(7-28), \beta-\mathrm{CN}(15-28)$ in other plasmintype cheeses such as in Grana Padano and Parmigiano Reggiano cheeses and the $\beta$ - $\mathrm{CN}(193-209)$, which is present regardless of the cheese technology used.

\section{AUTHOR INFORMATION}

\section{Corresponding Author}

*E-mail: valerie.gagnaire@rennes.inra.fr. Phone: +33 02234853 46. Fax: +33 (0)2 23485350 .

\section{REFERENCES}

(1) McSweeney, P. L. H. Biochemistry of cheese ripening. Int. J. Dairy Technol. 2004, 57, 127-144.

(2) Sousa, M. J.; Ardo, Y.; McSweeney, P. L. H. Advances in the study of proteolysis during cheese ripening. Int. Dairy J. 2001, 11, $327-345$.

(3) Creamer, L. K.; Olson, N. F. Rheological evaluation of maturing Cheddar cheese. J. Food Sci. 1982, 47, 631-636 and 646.

(4) Thierry, A.; Maillard, M. B. Production of cheese flavour compounds derived from amino acid catabolism by Propionibacterium freudenreichii. Lait 2002, 82, 17-32.

(5) Williams, A. G.; Noble, J.; Banks, J. M. Catabolism of amino acids by lactic acid bacteria isolated from Cheddar cheese. Int. Dairy J. 2001, 11, 203-215.

(6) Yvon, M.; Rijnen, L. Cheese flavour formation by amino acid catabolism. Int. Dairy J. 2001, 11, 185-201.

(7) Licitra, G.; Portelli, G.; Campo, P.; Longombardo, G.; Farina, G.; Carpino, S.; Barbano, D. Technology to produce Ragusano cheese: a survey. J. Dairy Sci. 1998, 81, 3343-3349.

(8) Gazzetta Ufficiale della Communita Europea. Registrazione delle indicazioni geografiche e della denominazioni di origine nel quatro della procedura di cui all' articolo 17 del Reg. to CEE n ${ }^{\circ}$ 2081/92. European Community, Brussels, Belgium, 1996.

(9) Carpino, S.; Mallia, S.; La Terra, S.; Melilli, C.; Licitra, G.; Acree, T. E.; Barbano, D. M.; Soest, P. J. Composition and aroma compounds of Ragusano cheese: native pasture and total mixed rations. J. Dairy Sci. 2004, 87, 816-830.

(10) Carpino, S.; Horne, J.; Melilli, C.; Licitra, G.; Barbano, D.; Soest, P. Contribution of native pasture to the sensory properties of Ragusano cheese. J. Dairy Sci. 2004, 87, 308-315.
(11) Fallico, V.; McSweeney, P. L. H.; Siebert, K.; Horne, J.; Carpino, S.; Licitra, G. Chemometric analysis of proteolysis during ripening of Ragusano cheese. J. Dairy Sci. 2004, 87, 3138-3152.

(12) Fallico, V.; Chianese, L.; Carpino, S.; Licitra, G. Qualitative and quantitative aspects of proteolysis during PDO Ragusano cheese ageing. Sci. Tec. Latt.-Casearia 2003, 54, 117-141.

(13) Alli, I.; Okoniewska, M.; Gibbs, B. F.; Konishi, Y. Identification of peptides in Cheddar cheese by electrospray ionization mass spectrometry. Int. Dairy J. 1998, 8, 643-649.

(14) Singh, T. K.; Fox, P. F.; Hojrup, P.; Healy, A. A scheme for the fractionation of cheese nitrogen and identification of principal peptides. Int. Dairy J. 1994, 4, 111-122.

(15) Gagnaire, V.; Mollé, D.; Herrouin, M.; Léonil, J. Peptides identified during Emmental cheese ripening: origin and proteolytic systems involved. J. Agric. Food Chem. 2001, 49, 4402-4413.

(16) Ferranti, P.; Barone, F.; Chianese, L.; Addeo, F.; Scaloni, A.; Pellegrino, L.; Resmini, P. Phosphopeptides from Grana Padano cheese: nature, origin and changes during ripening. J. Dairy Res. 1997, 64, 601-615.

(17) Sforza, S.; Ferroni, L.; Galaverna, G.; Dossena, A.; Marchelli, R. Extraction, semi-quantification, and fast on-line identification of oligopeptides in Grana Padano cheese by HPLC-MS. J. Agric. Food Chem. 2003, 51, 2130-2135.

(18) Gomez-Ruiz, J.; Taborda, G.; Amigo, L.; Recio, I.; Ramos, M. Identification of ACE-inhibitory peptides in different Spanish cheeses by tandem mass spectrometry. Eur. Food Res. Technol. 2006, 223, 595-601.

(19) Gomez-Ruiz, J. A.; Ramos, M.; Recio, I. Identification and formation of angiotensin-converting enzyme-inhibitory peptides in Manchego cheese by high-performance liquid chromatography-tandem mass spectrometry. J. Chromatogr., A 2004, 1054, 269-277.

(20) Addeo, F.; Chianese, L.; Salzano, A.; Sacchi, R.; Cappuccio, U.; Ferranti, P.; Malorni, A. Characterisation of the $12 \%$ trichloroacetic acidinsoluble oligopeptides of Parmigiano-Reggiano cheese. J. Dairy Res. 1992, 59, 401-411.

(21) Addeo, F.; Chianese, L.; Sacchi, R.; Spagna Musso, S.; Ferranti, P.; Malorni, A. Characterization of the oligopeptides of ParmigianoReggiano cheese soluble in $120 \mathrm{~g}$ trichloroacetic acid/l. J. Dairy Res. 1994, 61, 365-374.

(22) Rizzello, C.; Losito, I.; Gobbetti, M.; Carbonara, T.; Bari, M.; Zambonin, P. Antibacterial activities of peptides from the water-soluble extracts of Italian cheese varieties. J. Dairy Sci. 2005, 88, 2348-2360.

(23) International Dairy Federation. Milk. Determination of nitrogen content. Brussels, Belgium, 1993; standard method 20B.

(24) International Dairy Federation. Milk and milk products. Determination of fat content (general guidance on the use of butyrometric methods). Brussel, Belgium, 1997; standard method 152A.

(25) Association of Official Analytical Chemists. Official Methods of Analysis; AOAC: Gaithersburg, MD, 2000.

(26) Bynum, D.; Barbano, D. Whole milk reverse osmosis retentates for Cheddar cheese manufacture: chemical changes during aging. J. Dairy Sci. 1985, 68, 1-10.

(27) Andrews, A. T. Proteinases in normal bovine milk and their action on caseins. J. Dairy Res. 1983, 50, 45-55.

(28) Blakesley, R. W.; Boezi, J. A. A new staining technique for proteins in polyacrylamide gels using Coomassie brilliant blue G250. Anal. Biochem. 1977, 82, 580-582.

(29) Kuchroo, C. N.; Fox, P. F. Soluble nitrogen in Cheddar cheese: comparison of extraction procedures. Milchwissenschaft 1982, 37, 331-335.

(30) Fallico, V.; McSweeney, P. L. H.; Horne, J.; Pediliggieri, C.; Hannon, J.; Carpino, S.; Licitra, G. Evaluation of bitterness in Ragusano cheese. J. Dairy Sci. 2005, 88, 1288-1300.

(31) Licitra, G.; Campo, P.; Manenti, M.; Portelli, G.; Scuderi, S.; Carpino, S.; Barbano, D. Composition of Ragusano cheese during aging. J. Dairy Sci. 2000, 83, 404-411.

(32) Gobbetti, M.; Morea, M.; Baruzzi, F.; Corbo, M. R.; Matarante, A.; Considine, T.; Di Cagno, R.; Guinee, T.; Fox, P. F. Microbiological, compositional, biochemical and textural characterisation of Caciocavallo Pugliese cheese during ripening. Int. Dairy J. 2002, 12, 511-523. 
(33) Feeney, E. P.; Guinee, T. P.; Fox, P. F. Effect of pH and calcium concentration on proteolysis in Mozzarella cheese. J. Dairy Sci. 2002, $85,1646-1654$.

(34) Collin, J. C.; Berdagué, J. L.; Dognin-bergeret, M.; Grappin, R. Affinage et qualité du gruyère de Comté IV. Etude de la protéolyse. Lait 1987, 67, 299-318.

(35) Pecorari, M.; Fossa, E.; Sandri, S.; Mariani, P. Proteolysis progress during the ageing of Parmigiano-reggiano cheese (Italian). Sci. Tec. Latt.-Casearia 1997, 48, 61-72.

(36) Yun, J.; Barbano, D.; Kindstedt, P. Mozzarella cheese: impact of milling $\mathrm{pH}$ on chemical composition and proteolysis. J. Dairy Sci. 1993, 76, 3629-3638.

(37) Licitra, G.; Ogier, J. C.; Parayre, S.; Pediliggieri, C.; Carnemolla, T. M.; Falentin, H.; Madec, M. N.; Carpino, S.; Lortal, S. Variability of bacterial Biofilms of the "Tina" wood vats used in the ragusano cheesemaking process. Appl. Environ. Microbiol. 2007, 73, 6980-6987.

(38) Lortal, S.; Di Blasi, A.; Madec, M. N.; Pediliggieri, C.; Tuminello, L.; Tanguy, G.; Fauquant, J.; Lecuona, Y.; Campo, P.; Carpino, S.; Licitra, G. Tina wooden vat biofilm: a safe and highly efficient lactic acid bacteria delivering system in PDO Ragusano cheese making. Int. J. Food Microbiol. 2009, 132, 1-8.

(39) Gaiaschi, A.; Beretta, B.; Poiesi, C.; Conti, A.; Giuffrida, M. G.; Galli, C. L.; Restani, P. Proteolysis of $\beta$-casein as a marker of Grana Padano cheese ripening. J. Dairy Sci. 2001, 84, 60-65.

(40) Gaiaschi, A.; Beretta, B.; Poiesi, C.; Conti, A.; Giuffrida, M. G.; Galli, C. L.; Restani, P. Proteolysis of $\alpha$ s-casein as a marker of Grana Padano cheese ripening. J. Dairy Sci. 2000, 83, 2733-2739.

(41) Ferranti, P.; Itolli, E.; Barone, F.; Malorni, A.; Garro, G.; Laezza, P.; Chianese, L.; Migliaccio, F.; Stingo, V.; Addeo, F. Combined high resolution chromatographic techniques (FPLC and HPLC) and mass spectrometry-based identification of peptides and proteins in Grana Padano cheese. Lait 1997, 77, 683-697.

(42) Mayer, H. K.; Rockenbauer, C.; Mlcak, H. Evaluation of proteolysis in Parmesan cheese using electrophoresis and HPLC. Lait 1998, 78, 425-438.

(43) Malacarne, M.; Formaggioni, P.; Franceschi, P.; Summer, A.; Mariani, P. Proteolysis and lipolysis of Parmigiano-Reggiano cheese at different ripening periods: 12, 24, 55 and 96 months. Ann. Fac. Med. Vet. Parma 2006, 26, 145-164.

(44) Exterkate, F. A.; Alting, A. C.; Bruinenberg, P. G. Diversity of cell envelope proteinase specificiy among strains of Lactococcus lactis and its relationship to charge characteristics of the substrate-binding region. Appl. Environ. Microbiol. 1993, 59, 3640-3647.

(45) Juillard, V.; Laan, H.; Kunji, E. R. S.; Jeronimus-Stratingh, C. M.; Bruins, A. P.; Konings, W. N. The extracellular P I-type proteinase of Lactococcus lactis hydrolyzes $\beta$-casein into more than one hundred different oligopeptides. J. Bacteriol. 1995, 177, 3472-3478.

(46) Sadat-Mekmene, L.; Jardin, J.; Corre, C.; Mollé, D.; Richoux, R.; Delage, M.-M.; Lortal, S.; Gagnaire, V. Simultaneous presence of PrtH and $\mathrm{PrtH} 2$ proteinases in Lactobacillus helveticus strains improves breakdown of the pure $\alpha_{\mathrm{s} 1}$-casein. Appl. Environ. Microbiol. 2011, 77, 179-186.

(47) Hebert, E. M.; Mamone, G.; Picariello, G.; Raya, R. R.; Savoy, G.; Ferranti, P.; Addeo, F. Characterization of the pattern of $\alpha_{\mathrm{s} 1^{-}}$and $\beta$ casein breakdown and release of a bioactive peptide by a cell envelope proteinase from Lactobacillus delbrueckii subsp. lactis CRL 581. Appl. Environ. Microbiol. 2008, 74, 3682-3689.

(48) Singh, T.; Gripon, J.; Fox, P. Chromatographic analysis and identification of peptides in cheese. Bull. FIL-IDF 1999, 337, 17-23.

(49) Singh, T. K.; Fox, P. F.; Healy, A. Isolation and identification of further peptides in the diafiltration retentate of the water-soluble fraction of Cheddar cheese. J. Dairy Res. 1997, 64, 433-443.

(50) Deutsch, S. M.; Mollé, D.; Gagnaire, V.; Piot, M.; Atlan, D.; Lortal, S. Hydrolysis of sequenced $\beta$-casein peptides provides new insight into peptidase activity from thermophilic lactic acid bacteria and highlights the intrinsic resistance of phosphopeptides. Appl. Environ. Microbiol. 2000, 66, 5360-5367.

(51) Korhonen, H.; Pihlanto, A. Bioactive peptides: production and functionality. Int. Dairy J. 2006, 16, 945-960.
(52) Walther, B.; Schmid, A.; Sieber, R.; Wehrmuller, K. Cheese in nutrition and health. Dairy Sci. Technol. 2008, 88, 389-405.

(53) Exterkate, F. A.; Alting, A. C. The conversion of the $\alpha_{\mathrm{s} 1}$-casein(1-23)-fragment by the free and bound form of the cell-envelope proteinase of Lactococcus lactis subsp. cremoris under conditions prevailing in cheese. Syst. Appl. Microbiol. 1993, 16, 1-8.

(54) Macedo, A. C.; Vieira, M.; Po $\tau$ as, R.; Malcata, F. X. Peptide hydrolase system of lactic acid bacteria isolated from Serra da Estrela cheese. Int. Dairy J. 2000, 10, 769-774.

(55) Le Bars, D.; Gripon, J. C. Specificity of plasmin towards bovine

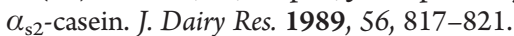

(56) Larsen, L. B.; Benfeldt, C.; Rasmussen, L. K.; Petersen, T. E. Bovine milk procathepsin $\mathrm{D}$ and cathepsin $\mathrm{D}$ : coagulation and milk protein degradation. J. Dairy Res. 1996, 63, 119-130. 